\title{
Comparative combinations of façade-building systems and thermal insulation materials for different climatic conditions: an environmental assessment
}

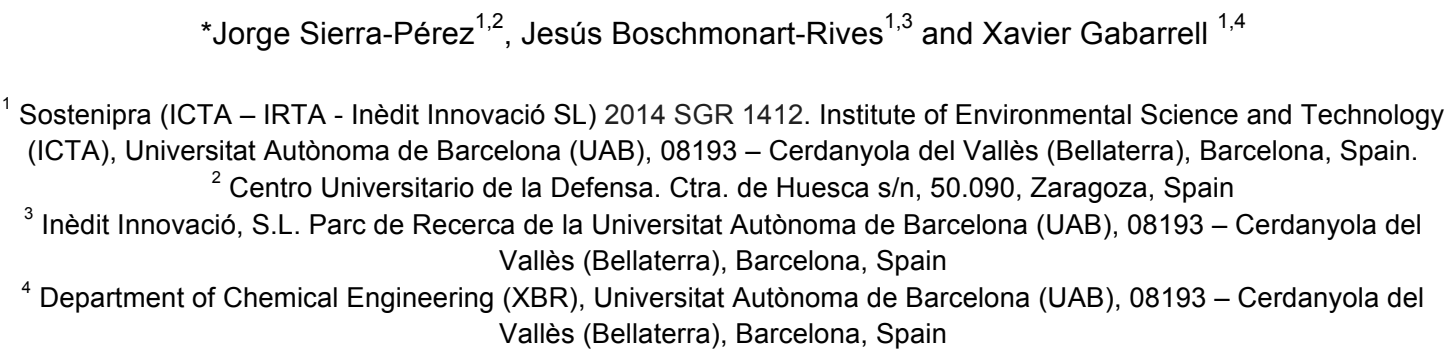

\section{Abstract}

In the European Union, the building sector accounts for more than $40 \%$ of the energy consumption and environmental impacts, representing the area with the greatest potential for intervention. In addition to the existing policies that promote the energy efficiency use in building, the embodied energy in the materials and the included processes in the building life cycle should be considered. Insulation materials are an essential part of the energy savings during the use of the building, but also of the embodied energy in the building construction. Most environmental studies about insulation materials at date had focused on the environmental impacts of the production of materials. This article aims to broaden the scope and provides a detailed environmental assessment of various thermal insulation materials applied in different types of façade systems in each Spanish climate zones by means of LCA from cradle to site approach methodology. The results show that the most impacting alternative is the ventilated façade in combination with the most impacting insulation materials: mineral wool and expanded polystyrene. Meanwhile the most advisable façade in all the climate zones is the external insulation option in combination with any alternative of insulation. The environmental impacts are very different between insulation materials, so it can be noted the relevance of the choice of the insulation. This behaviour is determined by the physical and insulation properties of different materials, but also the environmental performance of them.

\section{Keywords}

Insulation materials, LCA, environmental impacts, embodied energy, sustainable construction, building façade.

Pre-print of: Sierra-Pérez, Jorge, et al. "Environmental assessment of
façade-building systems and thermal insulation materials for different
climatic condicions" in Journal of Cleaner Production Vol. 113 (February
2016), p. 102-113. Elsevier. The final version is available at DOI 10.1016/
j.jclepro.2015.11.090


37 - Environmental impacts of common insulation applied in façade systems have 38 compared

$39 \cdot$ ETICS with any insulation and in any climate zone is the most sustainable alternative

40 . The most sustainable insulation is SW, meanwhile MW and EPS have the greatest 41 impacts

$42 \cdot$ Importance of insulation choice because their differences in environmental impacts

\section{$43 \quad$ Nomenclature}

\begin{tabular}{|c|c|}
\hline EPBD & Energy Performance of Buildings Directive \\
\hline XPS & Extruded polystyrene \\
\hline EPS & Expanded polystyrene \\
\hline PU & Polyurethane \\
\hline MW & Mineral wool \\
\hline ETICS & Stone wool \\
\hline NZEB & External Thermal Insulation Composite System \\
\hline SME & Small and medium-sized enterprises \\
\hline CO ${ }_{2}$ & Carbon dioxide \\
\hline LCA & Life cycle assessment \\
\hline DIN & German Institute for Standardization \\
\hline DU & Declared unit \\
\hline EN & European norm \\
\hline CML & Institute of Environmental Sciences \\
\hline ADP & Abiotic depletion potential \\
\hline AP & Acidification potential \\
\hline EP & Eutrophication potential \\
\hline GWP & Global warming potential \\
\hline OLDP & Ozone layer depletion \\
\hline PCOP & Photochemical oxidation \\
\hline EE & Embodied energy \\
\hline CED & Cumulative energy demand \\
\hline &
\end{tabular}

44 


\section{Introduction}

In the European Union (EU), the building sector represents one of the leading environmental points, accounting for more than $40 \%$ of the energy consumption and environmental impacts [1]. But also represents the area with the greatest potential for intervention [2], wherein increasing building energy efficiency is crucial for the transformation of the UE energetic framework [3]. Indeed, the sustainability concerns of Horizon 2020 could have a strong impact on the future of the European construction industry [4]. A more sustainable construction and use of buildings in the EU would decrease $42 \%$ of final energy consumption, about $35 \%$ of greenhouse gas emissions and more than $50 \%$ of all extracted materials. Moreover, it could also help us save up to $30 \%$ water [5]. Currently, existing policies promote energy efficiency and renewable energy use in buildings, i.e. the European Energy Performance of Buildings Directive 2002/91/EC (EPBD) [1]. This directive introduces the concept of nearly zero-energy building (NZEB), and establishes that all new constructions have to NZEB by the 31st of December of 2020. For public buildings, the deadline is even sooner - the end of 2018. The implementation of these regulations means less energy consumption during the use phase of the building, operating energy, expended in maintaining the inside environment through processes such as heating and cooling, lighting and operating appliances. In addition to operating energy, the total life cycle energy of a building also includes the embodied energy, the sequestered energy in building materials during all processes of production, on-site construction, final demolition and disposal. And consequently, it is concluded that much effort has been made towards the reduction of operational energy by increasing the energy efficiency of buildings. However, as operational energy is reduced, the percentage of the embodied energy in the total energy consumption of the buildings becomes increasingly prevalent [6-8]. Therefore, according to European Commission [5], it is needed to be further strengthened and complemented with policies for resource efficiency, which look at a wider range of environmental impacts across the life-cycle of buildings and infrastructure.

Recent studies on embodied energy and embodied $\mathrm{CO}_{2}$ have been developed [9-12], considering the significance of embodied energy and carbon inherent in building materials. A certain awareness of the embodied energy contents of building materials could encourage the use of not only production and development of low embodied energy materials, but also their preference among construction design and industry to require energy [13]. Consequently less use of resources will lead to fewer emissions and therefore reducing the environmental impacts in the construction of the building. Moreover a comprehensive assessment of the energy use and environmental impacts of buildings requires a life-cycle perspective to quantify the various impacts and to identify improvement opportunities towards more sustainable solutions. Life cycle assessment (LCA) methodology [13] has gained increased international acceptance in building sector, identifying the potential environmental impacts throughout a product life-cycle [14]. In addition to identifying improvements in the environmental performance of different constructive solutions, LCA is widely used to compare different alternatives in the design of buildings. On the one hand, most studies have focused on building solutions: different types of exterior walls [15-17], the structure of building [18] and more recently, the green roofs $[19,20]$. In these studies the parameters used to compare different alternatives are the composition of the building system and the 
materials used in each solution. As well as considering the location of the building as a parameter for comparison between alternatives [21-23]. On the other hand, LCA can be a support tool in the choice of the materials to include into the solutions. For example, Zabalza [24] used the process-based LCA framework to evaluate environmental impacts of different building materials used in different construction solutions, including: floors, roofs, the structure and insulation materials. It is this latter group of materials which has recently increased the interest in the environmental field [25-28].

The thermal insulation materials have an important role because, in addition to influencing the environmental impacts of construction, it will also influence in the use phase of the building. So a first move towards efficient use of operating energy is to reduce the energy required to keep a good interior temperature. According to the NZEB and the use of passive solutions for the envelope will result in increased insulation thicknesses in buildings. Thus, the contribution of these materials to the life cycle environmental impact of buildings will be critical [28], so that the environmental assessment of different insulation solutions has become an strategic issue in building. Almost all LCA of insulation materials performed are focused on the comparison between the environmental impacts generated by a given amount of material with the same thermal insulation requirements [2,28-33]. Nevertheless, very few international studies have included therewith an important factor to consider in comparing different building materials: how constructive solution will be installed [34,35]. These installation parameters are defined by the constructive system itself as well as the type and amount of material to place [36-38]. The amount of material to be installed will be also determined by the climatic conditions at the building location. So as has been noted above, any factor that influences the amount of insulating material should be included in their environmental assessments. Additionally, to our knowledge, no published information relating the effect of climatic conditions on optimum combination of façadebuilding systems and thermal insulation materials.

This paper can help to fill this gap and provide a detailed environmental impact assessment comparing different constructive systems in Spanish context, where exist different climate zones with diverse climatic conditions. Hence the desirability of either insulation material will be very different. The novelty of the paper also consists in the inclusion of the installation phase in the environmental assessment of thermal insulation materials, which are applied in different façade-building systems.

\section{Materials and methods}

\subsection{Objectives}

This article determines the best environmental alternative for the thermal insulation of a building façade located in Spain and evaluates the environmental impact of the most common types of façade systems. The specific objectives are:

- To elaborate an inventory of the materials, machinery and energy consumption in the production, transport and installation phases of the life cycle of the façade solutions analysed. 
- To assess the environmental impact of the different façade systems considering different insulation materials to determine what the less impactful constructive alternatives are under the climate conditions established.

- To compare the environmental impact of different insulation materials in each façade systems according to different climate zones established in Spain.

\subsection{Insulation materials under study}

The European market of insulation materials is still dominated by two groups of products. On the one hand the inorganic fibrous materials account for $60 \%$ of the market, primarily Mineral wool (MW) and Stone wool (SW). On the other hand the organic foamy materials account for about $30 \%$ of the market, the most common are expanded polystyrene (EPS), extruded polystyrene (XPS) and the less widespread polyurethane (PU) $[25,30]$. All other materials accounted for less than $13 \%$ together, among them: Insulation cork board (ICB), Wood wool, Aerogel, etc. These materials have been encouraged as efficient insulation and as sustainable solutions. But, few studies have been published about these alternative materials [2,28,39-43]. In summary, this study considers the environmental assessment of the most common materials: MW, SW, EPS, XPS and PU, representing $90 \%$ of the worldwide market.

\subsection{Description of the façade systems under study}

This section illustrates in detail the structural features of the various façade systems included in the study (Fig. 1). Also the process of construction and the installation of the components are described $[38,44]$.

\section{ETICS}

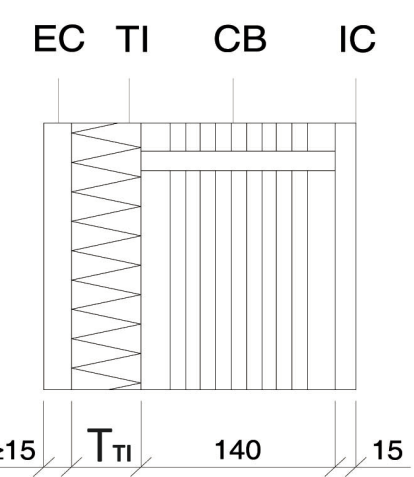

\section{Ventilated façade}

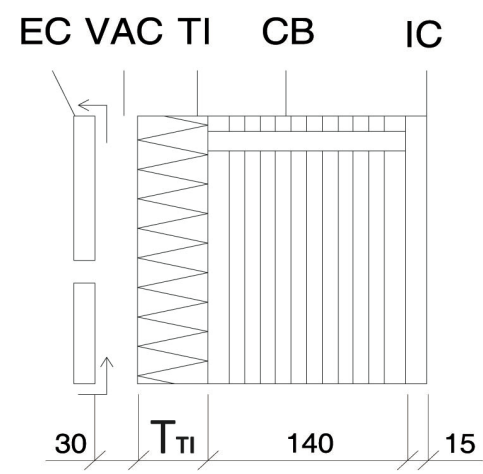

$T_{\mathrm{TI}}$ : Thickness Thermal Insulation

\section{Internal \\ insulation façade}

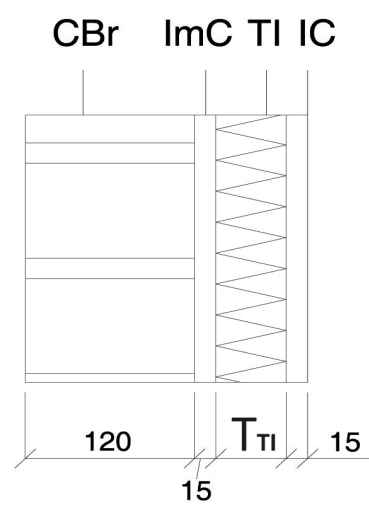

(units in $\mathrm{mm}$ )

CB: Ceramic Block; CBr: Concrete Brick; EC: External cladding; IC: Inner cladding; ImC: Intermediate cladding; TI: Thermal Insulation; VAC: Ventilated air chamber 
ETICS is a constructive solution for façade composed by multiple layers: the wall, the insulation material, the fixing on the substrate, the reinforcing intermediate coating and reinforcement mesh and a decorative finish coating. The objective of ETICS is to minimize the heat bridges and losses and to remain reliable and durable protecting the building against environmental and climatic factors. The system has to have high resistance to mechanical stress, impermeability to water and permeability to $\mathrm{CO}_{2}$ and to water vapor. Insulation boards are fixed on the wall with adhesive mortar and/or dish-shaped dowels depends on the quantity and type of insulation and the type of substrate.

\subsubsection{Ventilated façade}

The Ventilated façade is a system consisting of a multi-layered building envelope which an outer layer made of different materials (metal, stone, wood facade boards (bars), composite, ceramic granite, etc.) is mechanically connected with galvanized steel, stainless steel or aluminum frame to the inner layer. This inner layer is insulated from de outside with board or foam insulation and is attached with adhesive mortar and/or dish-shaped dowels, depends on the thickness and type of insulation. The ventilated façade allows free air circulation intermediate cavity that removes moisture and under the effect of the solar radiation, the energy performance of these façade systems improves in relation to conventional façades. Furthermore, the installation of the insulation material outside the main wall eliminates thermal bridges, i.e. a localised area of the building envelope where the heat flow is different (usually increased) in comparison with adjacent areas.

\subsubsection{Internal insulation façade}

The Internal insulation façade is a constructive solution of enclosure composed of outer main wall, insulation and inner cladding. The insulation layer is fixed with metallic profiles which are mechanically connected to the floor and ceiling. This system is the most usual for the construction of facades of new buildings and rehabilitation of existing buildings. The inner insulation separates the thermal mass of the walls of the living space and reduces both the response time and the energy required to achieve thermal comfort. It is one of the cheaper options but must take into account the interruption of insulation in the ceilings and walls encounters, so they can produce thermal bridge.

\subsection{Climate considerations in the selection of façade systems}

Considering the climate zone where the facade is located, it should take into account a several factors that can influence the performance of each of the solutions. The most important are:

1) Solar radiation that supports the façade.

2) The thermal inertia of the whole façade.

3) The evacuation of the possible condensation produced. 
For the first parameter, the facades located in warm zones will have more impact from sunlight; with high outside temperatures. For that, the ventilated facades prevents heat can enter into the building, keeping comfort temperatures in summer. In the case of ETICS, the color of the external coating avoids influence heat transfer, for example the white color will reflect the sunlight. In the case of the thermal inertia, it will influence climates where there are marked temperature changes between day and night. Therefore, the ceramic block, used in ETICS as internal wall, allows the maintenance of the temperature within the building although the outer conditions change throughout the day. Moreover, the rain or the temperature changes can cause the condensation of water vapor. In that case, ETICS is the least indicated in the wetlands, either by rain or coastal areas, since the outer coating is more easily degrade and need to add maintenance actions. To facilitate the evacuation of condensation water, different solutions included in the Internal insulation façade and Ventilated façade systems are recommended.

\subsection{Declared unit}

The declared unit (DU) is used instead of the functional unit when the precise function of the product or building-level scenarios is not stated or unknown. In this case, to insulate a given surface of a building façade, the amount of insulation material required will vary depending on the type of constructive solution or the geographic location of the building, among others. It has been established a DU according to the environmental product declaration (EDP) for construction products EN 15804:2014 [45] in order to compare the environmental impacts of the constructive solutions under study on the basis of the different insulation materials.

The DU is the production, transport and installation of the necessary quantity of materials to construct $1 \mathrm{~m}^{2}$ of three façade solutions selected: 1) ETICS, 2) Ventilated façade and 3) Internal insulated façade. And as noted above, the commonly used insulation materials in building have been selected for the study: EPS, XPS, PU, MW and SW. In order to establish the adequate quantity of each insulation material, the DU must be related with the heat transferred through it $[28,46,47]$, using the following equation to calculate the amount of insulation required:

$$
D U=R \lambda \rho A
$$

Where $R$ represents the thermal resistance $\left(\mathrm{m}^{2} \mathrm{~K} / \mathrm{W}\right)$, a heat property and a measurement of a temperature difference by which a material resists a heat flow. The greater the $R$ value is more insulation material. In addition the inverse of $R$ is used; it is called thermal transmittance $(U)$. The factor $\lambda$ is the thermal conductivity $(\mathrm{W} / \mathrm{m} \mathrm{K})$, the most important property of any thermal insulation material, i.e. the low capacity of a substance to transport thermal energy [48]. $\rho$ corresponds to the density of the material $\left(\mathrm{kg} / \mathrm{m}^{3}\right)$, it can be showed in Table 2. And $A$ is the surface of façade $\left(\mathrm{m}^{2}\right)$, in this case the value is $1 \mathrm{~m}^{2}$. Consequently, in the calculations required in order to decide the adequate quantity of the insulation material, it has been established a thermal transmittance value $\mathrm{U}=0.27\left(\mathrm{~W} / \mathrm{m}^{2} \mathrm{~K}\right)$ or $\mathrm{R}=3.7\left(\mathrm{~m}^{2} \mathrm{~K} / \mathrm{W}\right)$ to insulate façades over the course of 50 years (Table 2). These value is according to the parameters required by the Spanish Technical Building Code for a building located in a " $\mathrm{D}$ " climate zone, the largest climate zone in Spain [37]. 


\begin{tabular}{|c|c|c|c|c|c|c|}
\hline & & XPS & EPS & PU & MW & SW \\
\hline \multicolumn{2}{|c|}{ Thermal conductivity $(\lambda)(\mathrm{W} / \mathrm{m} \mathrm{K})$} & 0.032 & 0.035 & 0.023 & 0.039 & 0.036 \\
\hline \multicolumn{2}{|c|}{ Density $\left(\mathrm{kg} / \mathrm{m}^{3}\right)$} & 20 & 35 & 31 & 130 & 21.8 \\
\hline \multirow{2}{*}{ ETICS } & Thickness (m) & 0.10 & 0.11 & 0.07 & 0.13 & 0.12 \\
\hline & Weight (Kg) & 2.06 & 3.95 & 2.30 & 16.35 & 2.53 \\
\hline \multirow{2}{*}{ Ventilated façade } & Thickness (m) & 0.10 & 0.11 & 0.07 & 0.12 & 0.11 \\
\hline & Weight (Kg) & 2.0 & 3.8 & 2.2 & 15.8 & 2.5 \\
\hline \multirow{2}{*}{$\begin{array}{l}\text { Internal insulation } \\
\text { façade }\end{array}$} & Thickness (m) & 0.11 & 0.12 & 0.08 & 0.13 & 0.12 \\
\hline & Weight (Kg) & 2.2 & 4.2 & 2.5 & 17.5 & 2.7 \\
\hline
\end{tabular}

Table 2. Functional unit $(\mathrm{kg})$ required of insulation per façade solution to provide a thermal resistance in " $D$ " climate zone

Additionally, a sensitivity analysis focused in the location of the building has been performed. In Spain several climate zones have defined. The determination of climatic zones is obtained from the calculation of climatic severities of winter and summer as recorded contrasting localities, through the combination of the parameters degree days and solar radiation in the locality. Therefore the requirements of insulation are different, i.e. the data for thermal transmittance $(U)$ for each climate zone change, that is, the insulation thickness. Table 3 shows the insulation required in each climate zone per type of façade system, being " $\alpha$ " the warmest climate zone and " $E$ " the coldest.

\begin{tabular}{|c|c|c|c|c|c|c|c|}
\hline & XPS & EPS & PU & MW & SW \\
\hline \multicolumn{3}{|c|}{ Thermal conductivity $(\lambda)(\mathrm{W} / \mathrm{m} \mathrm{K})$} & 0.032 & 0.035 & 0.023 & 0.039 & 0.036 \\
\hline \multicolumn{3}{|c|}{ Density (kg/m3) } & 20 & 35 & 31 & 130 & 21.8 \\
\hline & & U-value & \multicolumn{5}{|c|}{ Thickness (m) } \\
\hline \multirow{5}{*}{ ETICS } & Climate $\alpha$ & 0.94 & 0.02 & 0.02 & 0.01 & 0.02 & 0.02 \\
\hline & Climate A & 0.5 & 0.05 & 0.05 & 0.03 & 0.06 & 0.05 \\
\hline & Climate B & 0.38 & 0.07 & 0.07 & 0.05 & 0.08 & 0.08 \\
\hline & Climate C & 0.29 & 0.09 & 0.1 & 0.07 & 0.11 & 0.11 \\
\hline & Climate E & 0.25 & 0.11 & 0.12 & 0.08 & 0.13 & 0.12 \\
\hline \multirow{5}{*}{$\begin{array}{l}\text { Ventilated } \\
\text { façade }\end{array}$} & Climate $\alpha$ & 0.94 & 0.01 & 0.02 & 0.01 & 0.02 & 0.02 \\
\hline & Climate A & 0.5 & 0.04 & 0.05 & 0.03 & 0.05 & 0.05 \\
\hline & Climate B & 0.38 & 0.06 & 0.07 & 0.05 & 0.08 & 0.07 \\
\hline & Climate C & 0.29 & 0.09 & 0.1 & 0.07 & 0.11 & 0.1 \\
\hline & Climate E & 0.25 & 0.11 & 0.12 & 0.08 & 0.13 & 0.12 \\
\hline \multirow{5}{*}{$\begin{array}{l}\text { Internal } \\
\text { insulation } \\
\text { façade }\end{array}$} & Climate $\alpha$ & 0.94 & 0.02 & 0.02 & 0.01 & 0.02 & 0.02 \\
\hline & Climate A & 0.5 & 0.05 & 0.06 & 0.04 & 0.06 & 0.06 \\
\hline & Climate B & 0.38 & 0.07 & 0.08 & 0.05 & 0.09 & 0.08 \\
\hline & Climate C & 0.29 & 0.1 & 0.11 & 0.07 & 0.12 & 0.11 \\
\hline & Climate $\mathrm{E}$ & 0.25 & 0.12 & 0.13 & 0.09 & 0.14 & 0.13 \\
\hline
\end{tabular}

Table 3. Functional unit $(\mathrm{m})$ required of insulation per façade solution to provide a thermal resistance in the climate zones established in Spain

\subsection{Methodology}

The LCA methodology is used in this paper, from a cradle to site approach, which means that environmental impacts analysis includes the production (extraction and processing of raw materials, transport to manufacturer and manufacturing), transport to 

has been used [49].

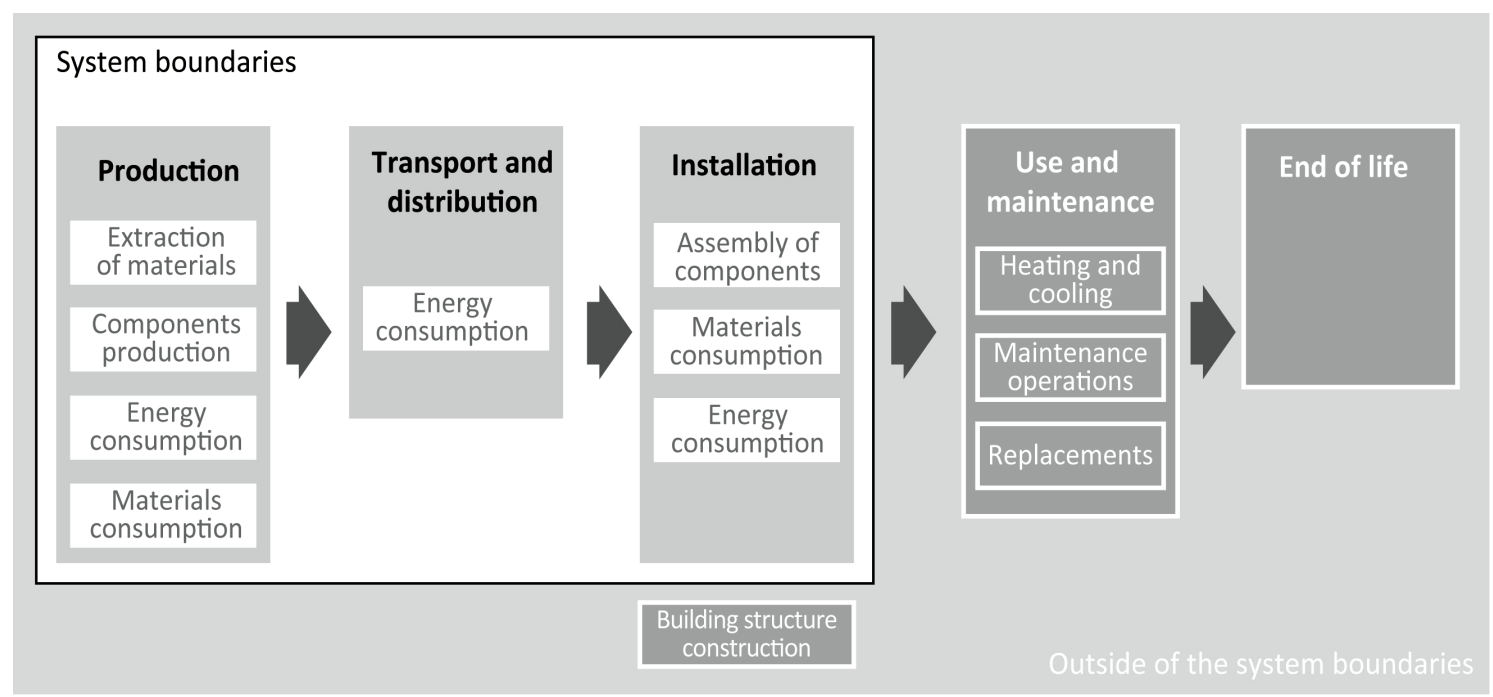

Figure 2. Diagram of the façade life cycle and system boundaries

According to the European standard that provides the core product category rules for all construction products and services, EN 15804:2014 [45], the following seven midpoint impact categories from the CML 2 baseline 2002 [50] were included in the assessment: abiotic depletion potential (ADP), acidification potential (AP), eutrophication potential (EP), global warming potential (GWP), ozone layer depletion (OLDP) and photochemical oxidation (PCOP). Additionally, as appointed above, the embodied energy (EE) or the cumulative energy demand (CED) has been included due to the increasing importance in the building energy demand.

\subsubsection{Environmental impact assessment of the constructive solutions}

The assessment of the façade systems requires data about the materials and quantity of the insulation, as well as installation data. According to the established DU and the building technical considerations, the Supplementary data indicates the materials and energy content for $1 \mathrm{~m}^{2}$ of the various façade systems.

For the installation phase, the materials and energy for the assembly of all components were considered. In the case of the insulation, different solutions for fixing exist: first depends on the façade system and second according the type of insulation materials and its thickness. The thickness depends on the climate conditions, and therefore the climatic zone where the building is located. In the case of ETICS and Ventilated façade, the insulation board is attached in the outside in all the climate zones. It has to be fixed with adhesive mortar for XPS and EPS and for thickness less than $40 \mathrm{~mm}$. The dish-shaped dowels are used for PU, MW and SW and for XPS and EPS boards with a thickness greater than $40 \mathrm{~mm}$. In the case of the "D" climate zone, all the insulation materials thickness are greater than $40 \mathrm{~mm}$, so all are fixed with the same elements: adhesive mortar and dish-shaped dowels. Also for Ventilated façade the fixation of insulation is made with the metals profiles that hold the external cladding. In the case of the Internal insulated façade the same fixation solution is used for all 
materials, thicknesses and climate zones: a structure made of metallic profiles attached to the ceiling and the floor and where the insulation boards are fitted.

Different sources of information were used in the process of collecting data for the inventory, Table 4 summarizes them.

\begin{tabular}{lllc}
\hline \multicolumn{1}{c}{ Source } & \multicolumn{1}{c}{ Data obtained } & Reference \\
\hline CSIC, 2008 & $\begin{array}{l}\text { Constructive description and dimensions } \\
\text { per façade solution }\end{array}$ & {$[36]$} \\
\hline $\begin{array}{l}\text { Ministerio de Vivienda, } \\
2013\end{array}$ & Thermal parameters for calculations & {$[37]$} \\
\hline Metabase Itec, 2010 & $\begin{array}{l}\text { Quantity of materials }\left(\mathrm{kg} / \mathrm{m}^{2} \text { of façade) }\right. \\
\text { Diesel consumption }(\mathrm{MJ} / \mathrm{h}) \text { and working } \\
\text { hours (h) for machinery }\end{array}$ & {$[51]$} \\
\hline Ecoinvent 3.1 database & $\begin{array}{l}\text { Environmental impacts of materials } \\
\text { extraction }\end{array}$ & {$[52]$} \\
\hline
\end{tabular}

Table 4. Summary of the data obtained from each data source

In order to determine the transport distance of each of the materials used in the construction, previous studies were consulted [32,53,54]. Finally, a distance of $100 \mathrm{~km}$ was assumed for all materials, due to their abundance, long distances are not common.

All the environmental information is taken from the same database, allowing the comparability of the different façade solutions and insulation materials. The database used to obtain the environmental information related with the processes involved with materials, energy and transport is ecoinvent 3.1 database [52].

\section{Results and discussion}

3.1. Comparison of the environmental impact of the different façade solutions

The life cycle impacts of $1 \mathrm{~m}^{2}$ of the various façade systems are presented in absolute values in Figure 3 and are disaggregated in following sections. 

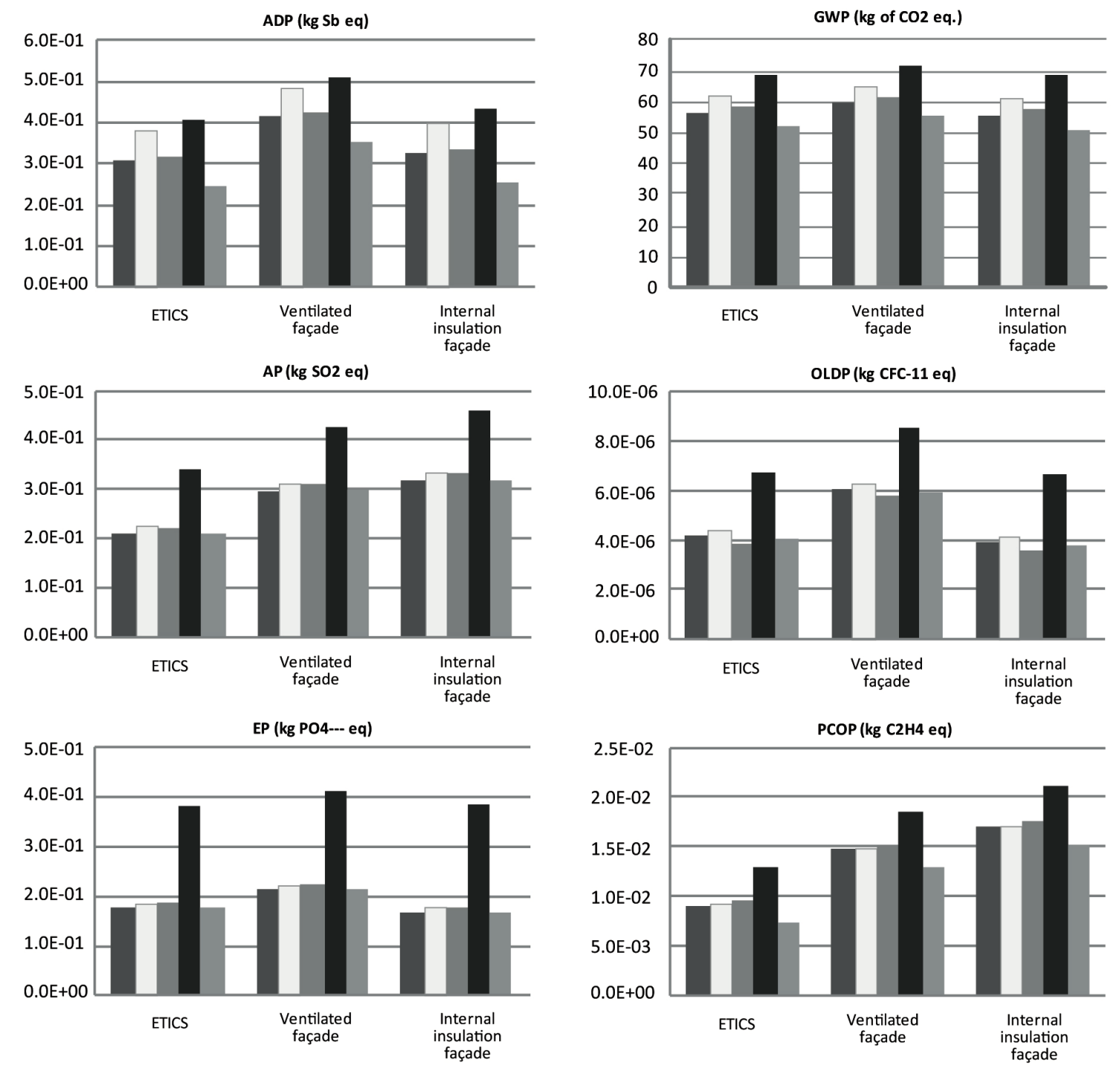

$\square$ XPS $\square$ EPS $\square$ PU $\square$ MW $\square W$

Figure 3. Comparative environmental impacts between façade systems with different insulation materials

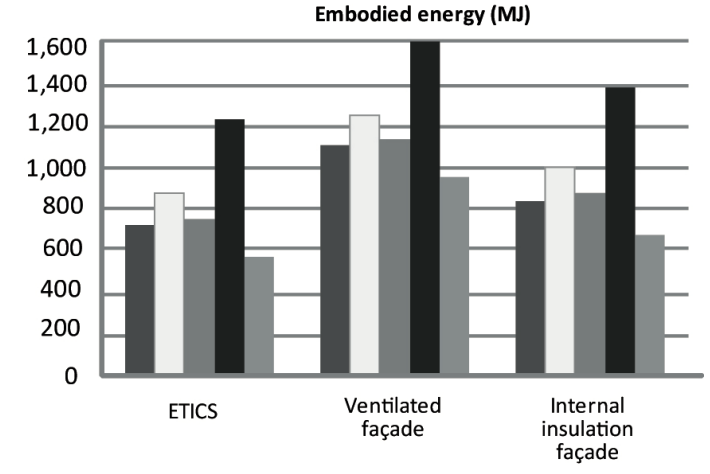

A comparison of the constructive solutions for façades reveals differences between the environmental impacts derived from each solution and also due to the insulation material used. Related to the constructive solutions, the Ventilated façade has the greatest impacts in most categories, except in AP and PCOP, on which the Internal Insulation Façade has greater impacts $6 \%$ and $13 \%$, respectively. ETICS has the lowest value in the most of categories, except for EP, GWP and OLDP, on which has similar values that Internal Insulation façade. The Ventilated façade system is a more complex construction solution than ETICS and Internal insulation façade, due to its better performance in energy efficiency during the use of building. In the case of EE 
category, there are important differences between façade systems, especially the ventilated facade with respect to other facade systems. The results for Ventilated façade are $30-70 \%$ greater than ETICS results and $15-40 \%$ greater than Internal insulation façade. The desirability of designing buildings with a particular type of facade will be analyzed in future studies which include how efficient are each façade system in the use phase of the building.

\subsubsection{Environmental impacts of production phase}

With regard to the disaggregated data by phase of the life cycle, in the case of ETICS and Ventilated façade the greatest impacts are concentrated in the production phase, accounting for $60-90 \%$ of global impact (Figure 3). As noted above, the Ventilated façade system is most complex than ETICS and Internal insulation façade systems. For that, in environmental terms, it is the façade system with largest impacts in production phase. But on the other hand, its performance during the use is better than others. In the case of ETICS, their construction system is not so complex, but the other life cycle phases not represent significant impacts. For the Internal insulation façade, the production phase accounts for between $20-70 \%$ of total impacts. Its constructive solution is very simple, containing few processes and materials associated with this phase.

\subsubsection{Environmental impacts of transport phase}

For the transport phase, the differences between the alternatives by type of constructive solution are related with the amount of material to construct $1 \mathrm{~m}^{2}$ of façade for each constructive system. Moreover, depends on the insulation material used, different quantity will be required for each alternative. Therefore the rest of material required is the same for each facade systems and, for that; the differences in the impact are derived from the production phase.

\subsubsection{Environmental impacts of installation phase}

It can be noted that the values used in the installation for each facade systems are the same in all the insulation alternatives as they are within the same climate zone. The insulating panels required in ETICS and Ventilated façade overcome the $400 \mathrm{~mm}$ of thickness; for that, they have to be fixed with dish-shaped dowels. For Internal insulation façade, the installation phase produces a great part of environmental impact in most of alternative insulation materials, reaching in several alternatives more than $70 \%$ of global impact. This phase exceeds the values of the production phase in all the SW impact categories and for the rest of insulation materials in AP, EP y OLDP and PCOP. This may be due to two reasons: 1 ) the constructive solution is very simple itself, so the production phase contains fewer processes and materials and hence is less relevant; and 2) the system used to fix the insulation boards are made from metallic material (aluminum profiles), which have a significant environmental impact. So an opportunity for environmental improvement is observed, either replacing the material profiles of fixation by a less impacting materials or developing a fixation system that requires less material.

The environmental impacts of transport and installation phase represent between 10$30 \%$ of the environmental impact in all categories. These impacts, according to the 
insulation material used, are greater the better environmental performance is the insulation material. This is due to the production phase is less relevant, in environmental terms, and so increase the importance of the other phases. Thus, the reduction of these environmental impacts involves the optimization of the process of installation, using simpler and less impacting material systems. Moreover, it should to optimize the quantity of insulation material used without committing the thermal requirements of the building.
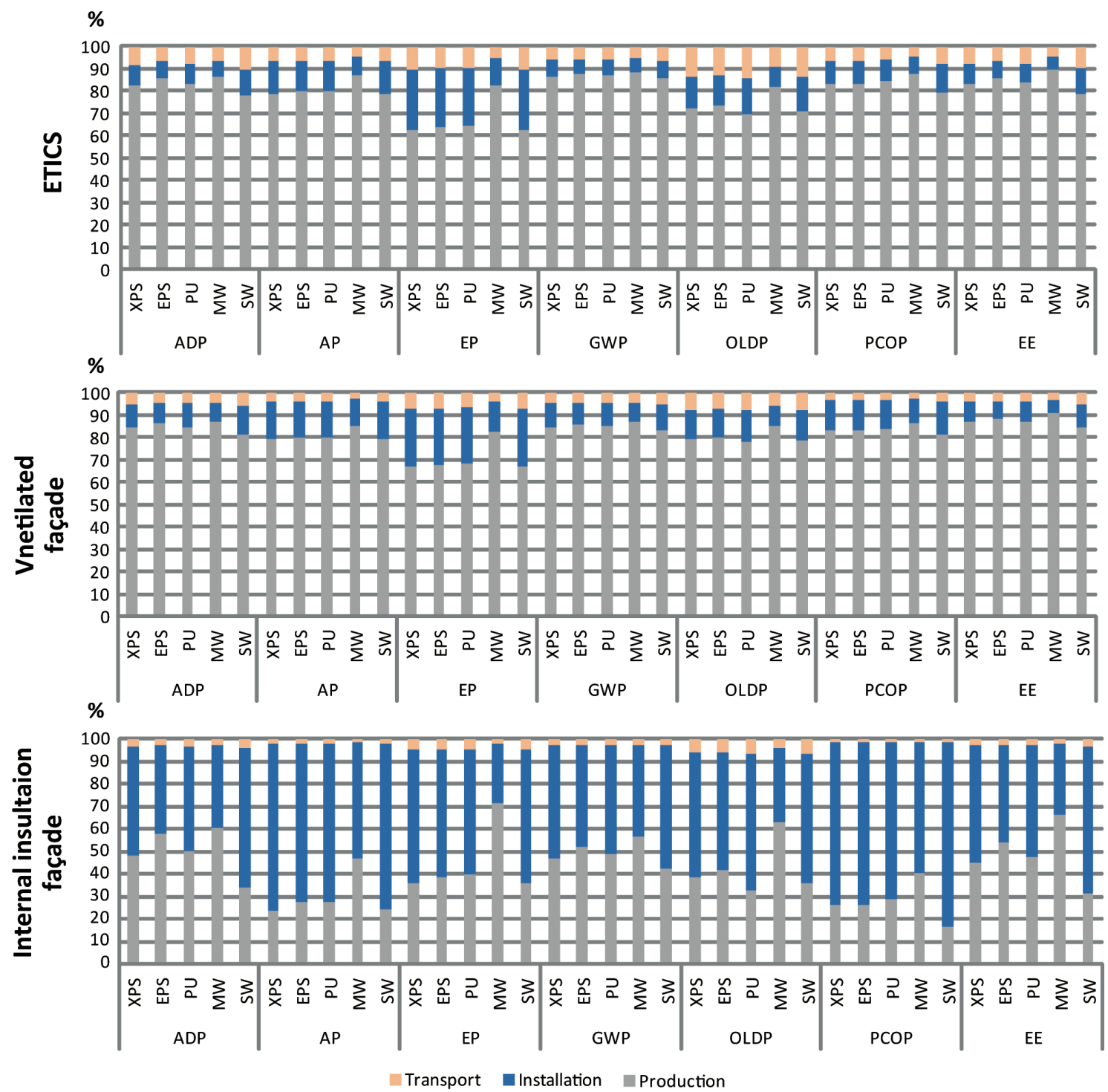

Figure 4.Contribution of each life cycle phase to the global environmental impact

\subsection{Environmental impact of the different insulation materials}

Previously, it has been noted the importance of the production phase for all the construction systems. Moreover, also is observed the influence of the insulation materials in the environmental behaviour of the façade systems. Table 5 shows the relation between the different insulation material impacts and the global impacts of the façade systems under study. It can be observed that the insulation material that contributes the most to the environmental impact is MW. More than $30 \%$ in the most of 
categories for all façade systems, and even for some categories its contribution exceeds $50 \%$ of the global impact (EP, PCOP and EE). The least impacting insulation material is SW, which contributions are between 4 and $14 \%$ of global impact for all categories and façade systems. Moreover, Table 5 shows the differences between the environmental performances of each insulation material in each constructive solution. This is due to the differences in the structure of the façade systems, varying the 375 amount and type of materials that form. For that, insulation materials will have more importance on environmental performance in the simplest systems construction; e.g. ETICS and Internal insulation façade.

\begin{tabular}{|c|c|c|c|c|c|c|c|c|c|c|c|c|c|c|c|}
\hline & \multicolumn{5}{|c|}{ ETICS } & \multicolumn{5}{|c|}{ Ventilated façade } & \multicolumn{5}{|c|}{ Internal insulation façade } \\
\hline & XPS & EPS & PU & MW & SW & XPS & EPS & PU & MW & SW & XPS & EPS & PU & MW & SW \\
\hline $\begin{array}{c}\text { ADP } \\
\text { (kg sb eq) }\end{array}$ & $8.8 \mathrm{E}-02$ & $1.6 \mathrm{E}-01$ & $9.9 \mathrm{E}-02$ & $1.9 \mathrm{E}-01$ & $2.4 \mathrm{E}-02$ & 2.1E-01 & $1.5 \mathrm{E}-01$ & $9.6 \mathrm{E}-02$ & $1.8 \mathrm{E}-01$ & 2.3E-02 & $9.4 \mathrm{E}-02$ & $1.7 \mathrm{E}-01$ & $1.1 \mathrm{E}-01$ & $2.0 \mathrm{E}-01$ & $2.6 \mathrm{E}-02$ \\
\hline$\underset{(\mathrm{kg} \mathrm{sO2} \text { eq) }}{\mathrm{AP}}$ & 2.8E-02 & $2.8 \mathrm{E}-02$ & $1.9 \mathrm{E}-01$ & $1.6 \mathrm{E}-01$ & $3.0 \mathrm{E}-02$ & $2.8 \mathrm{E}-02$ & $4.2 \mathrm{E}-02$ & 4.1E-02 & $1.5 \mathrm{E}-01$ & $2.9 \mathrm{E}-02$ & $3.0 \mathrm{E}-02$ & $4.6 \mathrm{E}-02$ & 4.6E-02 & $1.7 \mathrm{E}-01$ & $3.2 \mathrm{E}-02$ \\
\hline $\begin{array}{c}\text { EP } \\
\text { (kg PO4--- eq) }\end{array}$ & $1.6 \mathrm{E}-02$ & 2.3E-02 & 2.6E-02 & 2.2E-01 & $1.6 \mathrm{E}-02$ & $1.5 \mathrm{E}-02$ & $2.2 \mathrm{E}-02$ & 2.5E-02 & 2.1E-01 & $1.6 \mathrm{E}-02$ & 1.7E-02 & $2.5 \mathrm{E}-02$ & 2.7E-02 & 2.3E-01 & 2.3E-01 \\
\hline $\begin{array}{c}\text { GWP } \\
\text { (kg CO2 eq) }\end{array}$ & $8.0 E+00$ & $1.3 \mathrm{E}+01$ & $1.0 \mathrm{E}+01$ & $2.0 \mathrm{E}+01$ & $3.7 \mathrm{E}+00$ & $7.7 \mathrm{E}+00$ & $1.3 E+01$ & $9.7 \mathrm{E}+00$ & $1.9 \mathrm{E}+01$ & $3.6 \mathrm{E}+00$ & $8.5 \mathrm{E}+00$ & $1.4 \mathrm{E}+01$ & $1.1 \mathrm{E}+01$ & $2.1 \mathrm{E}+01$ & $3.9 \mathrm{E}+00$ \\
\hline $\begin{array}{c}\text { OLDP } \\
\text { (kg CFC-11 eq) }\end{array}$ & 4.3E-07 & 6.4E-07 & $1.0 \mathrm{E}-07$ & $2.9 \mathrm{E}-06$ & $2.8 \mathrm{E}-07$ & $4.2 \mathrm{E}-07$ & $6.2 \mathrm{E}-07$ & $1.0 \mathrm{E}-07$ & $2.9 \mathrm{E}-06$ & 2.7E-07 & $4.6 \mathrm{E}-07$ & $6.8 \mathrm{E}-07$ & 1.1E-07 & $3.2 \mathrm{E}-06$ & $3.0 \mathrm{E}-07$ \\
\hline $\begin{array}{c}\text { PCOP } \\
(\mathrm{kg} \mathrm{C} 2 \mathrm{H} 4 \text { eq) }\end{array}$ & $2.6 \mathrm{E}-03$ & 2.7E-03 & $3.2 \mathrm{E}-03$ & $6.5 \mathrm{E}-03$ & $8.7 \mathrm{E}-04$ & $2.6 \mathrm{E}-03$ & $2.6 \mathrm{E}-03$ & $3.1 \mathrm{E}-03$ & $6.3 \mathrm{E}-03$ & $8.5 \mathrm{E}-04$ & $2.8 \mathrm{E}-03$ & $2.9 \mathrm{E}-03$ & 3.4E-03 & $6.9 \mathrm{E}-03$ & $9.3 \mathrm{E}-04$ \\
\hline $\begin{array}{l}\text { EE } \\
\text { (MJ) }\end{array}$ & $2.0 \mathrm{E}+02$ & $3.5 \mathrm{E}+02$ & $2.3 \mathrm{E}+02$ & $7.1 \mathrm{E}+02$ & $4.9 \mathrm{E}+01$ & $2.0 \mathrm{E}+02$ & $3.4 \mathrm{E}+02$ & $2.3 \mathrm{E}+02$ & $6.9 \mathrm{E}+02$ & $4.8 \mathrm{E}+01$ & $2.2 \mathrm{E}+02$ & $3.8 \mathrm{E}+02$ & $2.5 \mathrm{E}+02$ & $7.6 \mathrm{E}+02$ & $5.3 E+01$ \\
\hline
\end{tabular}

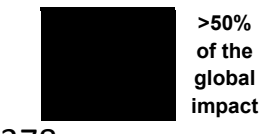

378

379

380

381

382

383

384

385

386

387

388

389

390

391

392

393

394

395

396

397 than MW.
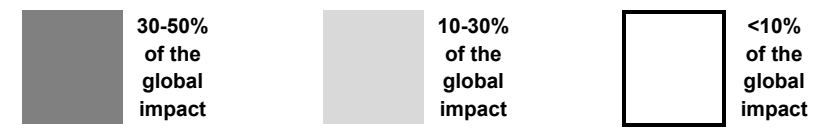

Table 5. Relation between the environmental impacts of the insulation materials and the global impacts of the façade systems

MW presents the highest environmental impacts in all categories and an impact up to 2 times greater than all the insulation material for almost all the categories (except ADP and GWP). The second most impacting material is EPS but its environmental impacts are far from MW results, between a 15 to $90 \%$ lower impact than MW. XPS and PU have similar results in almost all the categories, between a 10 to $50 \%$ lower impact

\subsection{Environmental impacts according to the climate zone}

As pointed above, a sensitivity analysis focused in the location of the building has been performed in terms of GWP and EE. Figure 5 shows differences between the impacts generated by each type of building facades depending on the area where the building is constructed. Looking at the data for the warmer zone, the a zone, the Ventilated facades are the systems which generate more impacts, both GWP and EE. ETICS and Internal insulation façade are the less impacting systems, with similar values in terms of GWP. But if we attend at the EE data, ETICS is the system with the lowest energy contained. As the climate zone is colder, the environmental behaviour patterns are not uniform within a constructive solution. It is noted a trend in which the critical parameter is the type of insulating material used; this issue will be discussed in the next section. 

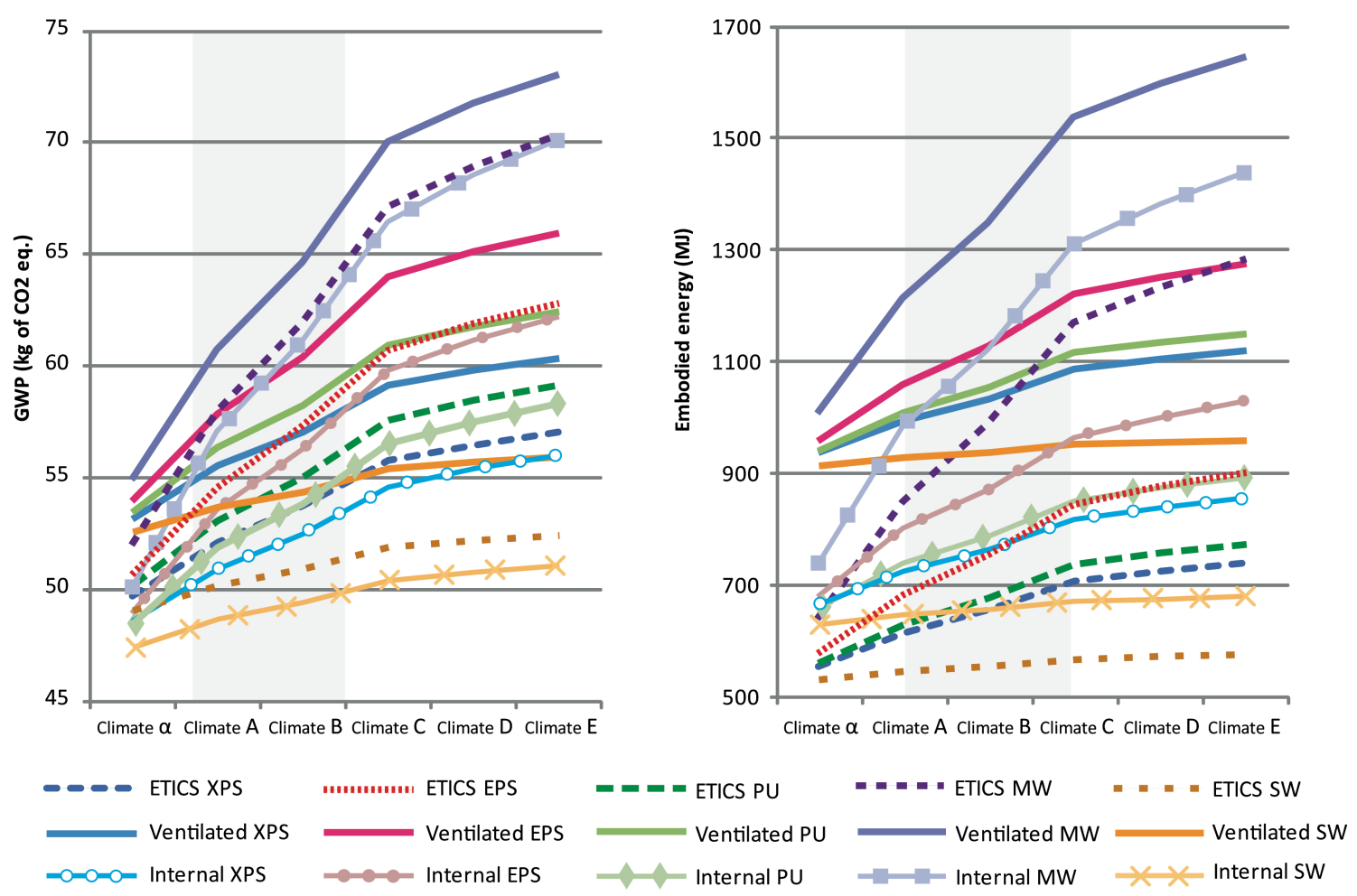

Figure 5. Comparison of the environmental impacts of different façade systems with different insulation materials in different climate areas

If we focus on the type of facade system by type of climatic zone, the most recommended one from an environmental approach for warmer zones is ETICS. Although in coastal areas, as noted above, the outside coating of ETICS will need maintenance due to these adverse conditions. From a technical point of view, the ventilated facade would be the most recommended, despite of having a higher percentage of impact. For colder climates, the most advisable solution facade would be ETICS, in terms of EE, depending on the selected insulating material. Although one should be analyzed the climatic conditions of humidity, considering the maintenance that should suffer this type of façade in the future. The interest of construct this type of façade should be analyzed more extensively including the use phase in future studies.

Regarding to the insulation materials, if we consider the geographical location of the building, the parameter of the weather has to be taken into account. For that, the thermal insulation needs will vary the quantity of insulation materials required in each climate zones. As colder is the location of the building largest amount of insulation will be necessary, therefore greater environmental impact. This will increase the influence of insulation on the overall impact in all the façade systems. The influence of this parameter is shown in Table 6, in terms of GWP and EE, for the climate zones defined in Spain.

In terms of GWP, it can be observed a marked increase in the importance of thermal insulation according cooler is the area under study. The most advisable material is the SW, which has impact values lower than $10 \%$ for all facade systems in all climatic zones. Also XPS and PU have lower values of $10 \%$ in the $\alpha$ and $A$ zones. In terms of $E E$, insulation has a great importance in systems building facades. Some of the materials under study exceed in most climate zones of more than $20 \%$ of the total 
embodied energy of the façade system. In coldest zones (zones C, D and E), the combination of ETICS and Internal façade insulation with EPS, PU and MW materials account for over $30 \%$ of global impact. On the other hand the SW material has a lower impact than $10 \%$ of the overall impact in all façade systems and in all climatic zones. Meanwhile, in the case of Ventilated façade all the insulation materials have the lowest percentages of total impacts in each climate zone. Although as discussed above the components of this constructive system has a global impact greater than other façade systems.

\begin{tabular}{|c|c|c|c|c|c|c|c|c|c|c|c|}
\hline & \multicolumn{5}{|c|}{ GWP (kg CO${ }_{2}$ eq.) } & \multicolumn{5}{|c|}{ EE (MJ) } \\
\hline & & XPS & EPS & PU & MW & SW & XPS & EPS & PU & MW & SW \\
\hline \multirow{3}{*}{ Clima $\alpha$} & ETICS & $1.3 E+00$ & $2.3 \mathrm{E}+00$ & $1.7 \mathrm{E}+00$ & $3.4 \mathrm{E}+00$ & $6.2 \mathrm{E}-01$ & $3.4 \mathrm{E}+01$ & $6.0 \mathrm{E}+01$ & $4.0 \mathrm{E}+01$ & $1.2 \mathrm{E}+02$ & $8.3 \mathrm{E}+00$ \\
\hline & Ventilated & $1.1 \mathrm{E}+00$ & $1.9 \mathrm{E}+00$ & $1.4 \mathrm{E}+00$ & $2.8 \mathrm{E}+00$ & $5.2 \mathrm{E}-01$ & $2.9 \mathrm{E}+01$ & $5.0 \mathrm{E}+01$ & $3.3 \mathrm{E}+01$ & $1.0 \mathrm{E}+02$ & $6.9 \mathrm{E}+00$ \\
\hline & Internal & $1.8 \mathrm{E}+00$ & $2.2 \mathrm{E}+00$ & $1.6 \mathrm{E}+00$ & $3.3 \mathrm{E}+00$ & $6.0 \mathrm{E}-01$ & $4.5 \mathrm{E}+01$ & $5.8 \mathrm{E}+01$ & $3.8 \mathrm{E}+01$ & $1.2 \mathrm{E}+02$ & $8.0 \mathrm{E}+00$ \\
\hline \multirow{3}{*}{ Clima A } & ETICS & $3.7 E+00$ & $6.2 \mathrm{E}+00$ & $4.6 \mathrm{E}+00$ & $9.3 \mathrm{E}+00$ & $1.7 \mathrm{E}+00$ & $9.4 \mathrm{E}+01$ & $1.6 \mathrm{E}+02$ & $1.1 \mathrm{E}+02$ & $3.3 \mathrm{E}+02$ & $2.3 \mathrm{E}+01$ \\
\hline & Ventilated & $3.4 \mathrm{E}+00$ & $5.8 \mathrm{E}+00$ & $4.3 E+00$ & $8.6 \mathrm{E}+00$ & $1.6 \mathrm{E}+00$ & $8.7 E+01$ & $1.5 \mathrm{E}+02$ & $1.0 \mathrm{E}+02$ & $3.1 \mathrm{E}+02$ & $2.1 \mathrm{E}+01$ \\
\hline & Internal & $4.1 \mathrm{E}+00$ & $6.8 \mathrm{E}+00$ & $5.1 \mathrm{E}+00$ & $1.0 \mathrm{E}+01$ & $1.9 \mathrm{E}+00$ & $1.0 \mathrm{E}+02$ & $1.8 \mathrm{E}+02$ & $1.2 E+02$ & $3.6 \mathrm{E}+02$ & $2.5 \mathrm{E}+01$ \\
\hline \multirow{3}{*}{ Clima B } & ETICS & $5.3 \mathrm{E}+00$ & $8.8 \mathrm{E}+00$ & $6.6 \mathrm{E}+00$ & $1.3 \mathrm{E}+01$ & $2.4 \mathrm{E}+00$ & $1.3 \mathrm{E}+02$ & $2.3 E+02$ & $1.5 \mathrm{E}+02$ & 4.7E+02 & $3.2 \mathrm{E}+01$ \\
\hline & Ventilated & $5.0 \mathrm{E}+00$ & $8.3 E+00$ & $6.2 E+00$ & $1.2 \mathrm{E}+01$ & $2.3 E+00$ & $1.3 \mathrm{E}+02$ & $2.2 \mathrm{E}+02$ & $1.5 \mathrm{E}+02$ & $4.4 \mathrm{E}+02$ & $3.0 \mathrm{E}+01$ \\
\hline & Internal & $5.6 \mathrm{E}+00$ & $9.4 \mathrm{E}+00$ & $7.0 \mathrm{E}+00$ & $1.4 \mathrm{E}+01$ & $2.6 \mathrm{E}+00$ & $1.4 \mathrm{E}+02$ & $2.5 \mathrm{E}+02$ & $1.7 E+02$ & $5.0 \mathrm{E}+02$ & $3.5 \mathrm{E}+01$ \\
\hline \multirow{3}{*}{ Clima C } & ETICS & $7.3 E+00$ & $1.2 \mathrm{E}+01$ & $9.1 \mathrm{E}+00$ & $1.8 \mathrm{E}+01$ & $3.4 \mathrm{E}+00$ & $1.9 \mathrm{E}+02$ & $3.2 \mathrm{E}+02$ & $2.1 \mathrm{E}+02$ & $6.5 E+02$ & $4.5 \mathrm{E}+01$ \\
\hline & Ventilated & $7.1 \mathrm{E}+00$ & $1.2 \mathrm{E}+01$ & $8.8 \mathrm{E}+00$ & $1.8 \mathrm{E}+01$ & $3.3 \mathrm{E}+00$ & $1.8 \mathrm{E}+02$ & $3.1 \mathrm{E}+02$ & $2.1 \mathrm{E}+02$ & $6.3 E+02$ & $4.4 \mathrm{E}+01$ \\
\hline & Internal & $7.7 \mathrm{E}+00$ & $1.3 E+01$ & $9.7 \mathrm{E}+00$ & $1.9 \mathrm{E}+01$ & $3.6 \mathrm{E}+00$ & $2.0 \mathrm{E}+02$ & $3.4 \mathrm{E}+02$ & $2.3 \mathrm{E}+02$ & $6.9 E+02$ & $4.8 \mathrm{E}+01$ \\
\hline \multirow{3}{*}{ Clima D } & ETICS & $8.0 \mathrm{E}+00$ & $1.3 E+01$ & $1.0 \mathrm{E}+01$ & $2.0 \mathrm{E}+01$ & $3.7 \mathrm{E}+00$ & $2.0 \mathrm{E}+02$ & $3.5 E+02$ & $2.3 E+02$ & $7.1 \mathrm{E}+02$ & $4.9 \mathrm{E}+01$ \\
\hline & Ventilated & $7.7 E+00$ & $1.3 E+01$ & $9.7 E+00$ & $1.9 \mathrm{E}+01$ & $3.6 \mathrm{E}+00$ & $2.0 \mathrm{E}+02$ & $3.4 \mathrm{E}+02$ & $2.3 \mathrm{E}+02$ & $6.9 E+02$ & $4.8 \mathrm{E}+01$ \\
\hline & Internal & $8.5 E+00$ & $1.4 \mathrm{E}+01$ & $1.1 \mathrm{E}+01$ & 2.1E+01 & $3.9 E+00$ & $2.2 \mathrm{E}+02$ & $3.8 \mathrm{E}+02$ & $2.5 \mathrm{E}+02$ & $7.6 E+02$ & $5.3 \mathrm{E}+01$ \\
\hline \multirow{3}{*}{ Clima E } & ETICS & $8.5 E+00$ & $1.4 \mathrm{E}+01$ & $1.1 \mathrm{E}+01$ & $2.1 E+01$ & $3.9 \mathrm{E}+00$ & $2.2 \mathrm{E}+02$ & $3.8 \mathrm{E}+02$ & $2.5 E+02$ & $7.6 \mathrm{E}+02$ & $5.3 \mathrm{E}+01$ \\
\hline & Ventilated & $8.3 \mathrm{E}+00$ & $1.4 \mathrm{E}+01$ & $1.0 \mathrm{E}+01$ & $2.1 \mathrm{E}+01$ & $3.8 \mathrm{E}+00$ & 2.1E+02 & $3.7 \mathrm{E}+02$ & $2.4 \mathrm{E}+02$ & $7.3 E+02$ & $5.1 \mathrm{E}+01$ \\
\hline & Internal & $9.2 \mathrm{E}+00$ & $1.5 \mathrm{E}+01$ & $1.1 \mathrm{E}+01$ & $2.3 E+01$ & $4.2 E+00$ & $2.3 \mathrm{E}+02$ & $4.1 \mathrm{E}+02$ & $2.7 E+02$ & $8.1 E+02$ & $5.6 \mathrm{E}+01$ \\
\hline
\end{tabular}

$>\mathbf{3 0} \%$ of the global impact

$<10 \%$ of the global impact

Table 6. Comparison of the environmental impacts of insulation materials in different façade systems located in the various climate zones defined in Spain

In Figure 5, it can be compared the different combination between façade systems and insulation material according to climatic zone. In the warmest zones, the choice of the insulation material has a lower influence in the environmental performance of the whole façade. This is because the lower insulation requirements, and therefore the type of façade have the greatest influence. The importance in the choice of insulating material increases as the temperature zone is cooler. The combination of ventilated facade with MW is the most impacting to all climatic zones in terms GWP and EE. Moreover, the combination of Internal insulation façade with SW is the least impacting in GWP terms, and the combination of ETICS with SW in EE terms. As can be observed, all the combinations with SW have the least environmental impact with increasing need for thermal insulation. On the other hand, MW presents the greatest increases for all the 
triples the least. For that, it can be pointed the importance of the choice of the type of façade system and insulation material, depending on the climate zone where the building is located.

\section{Conclusions}

The results show that the most impacting alternative of façade is the Ventilated façade in combination with the insulation materials with highest environmental impacts: MW and EPS. MW represents between $30-50 \%$ of the global impacts in the most of categories for all façade systems, and EPS between a 15 to $90 \%$ lower impact than MW. On the other hand SW presents the lowest environmental impacts in almost all the categories between an 80 to $95 \%$ lower impact than MW. This behaviour is determined by the physical and insulation properties of different materials, but also the environmental performance of them. Insulation materials are an important part in the environmental impacts of the production phase, which in turn represents the most impacting phase for ETICS and Ventilated façade. So it can be noted the relevance of the choice of the insulation.

The whole constructive solution where the insulation materials are installed must be considered in order to not omit the environmental impacts of the materials transport and installation phases. In the case of ETICS and Ventilated façade can represent between $10-30 \%$ of the global environmental impact in all categories. The installation phase is especially relevant for Internal insulation façade, where the environmental impacts accounts for between $30-90 \%$ for all categories. The environmental impacts of transport and installation phase according to the insulation material used are greater the better environmental performance is the insulation material. This is due to the production phase is less relevant, in environmental terms, and so increase the importance of the other phases. Thus, the reduction of these environmental impacts involves the optimization of the process of installation, using simpler and less impacting material systems. Moreover, it should optimize the quantity of insulation material used without committing the thermal requirements of the building.

In addition, if the climate conditions where the building is located within Spain are taken into account, the thermal and construction requirements change, and therefore the need for insulation and the suitability of a particular facade system. In warm zones, the most recommended façade system is ETICS, especially in terms of embodied energy. Although in coastal areas, as noted above, the outside coating of ETICS will need maintenance due to these adverse conditions. From a technical point of view, the ventilated facade would be the most recommended, despite of having important environmental impacts. For colder climates, the most advisable solution facade would be ETICS, in terms of EE, depending on the selected insulating material. Although one should be analyzed the climatic conditions of humidity, considering the maintenance that should suffer this type of façade in the future. In the particular case of Spain, due to its aging housing park, it should extend this study to the case of rehabilitation. Therefore, it could be analysed how the impact generated in rehabilitation is compensated due to improved insulation of the façade.

The methodology proposed can be applied to any constructive solution as well as to 
489 developers, architects and urban planners, to calculate the environmental impacts 490 derived from the building construction, which is useful for decision making during the 491 design of the building. In future studies the use phase of the building will be taken into 492 account in order to include the energy needs for heating or cooling the inside. It will be 493 discussed the environmental influence of the insulation materials according to the 494 façade systems and their performance during the use.

495 


\section{References}

[1] Comission E. Energy Performance of Buildings Directive 2010/31/EU (EPBD). Brusels: 2010.

[2] Proietti S, Desideri U, Sdringola P, Zepparelli F. Carbon footprint of a reflective foil and comparison with other solutions for thermal insulation in building envelope. Appl Energy 2013;112:843-55. doi:10.1016/j.apenergy.2013.01.086.

[3] COM 885/2. Energy Roadmap 2050. Brussels: 2011.

[4] Pacheco-Torgal F. Eco-efficient construction and building materials research under the EU Framework Programme Horizon 2020. Constr Build Mater 2014;51:151-62. doi:10.1016/j.conbuildmat.2013.10.058.

[5] COM 571. Road map to a resource efficient Europe. Brusels: 2011.

[6] Thormark C. A low energy building in a life cycle - its embodied energy , energy need for operation and recycling potential 2002;37:429-35.

[7] Pacheco-Torgal F, Faria J, Jalali S. Embodied Energy Versus Operational Energy . Showing The Shortcomings Of The Energy Performance Building Directive ( EPBD ) 2010.

[8] Pacheco-Torgal F. Eco-efficient construction and building materials research under the EU Framework Programme Horizon 2020. Constr Build Mater 2014;51:151-62. doi:10.1016/j.conbuildmat.2013.10.058.

[9] Dixit MK, Fernández-Solís JL, Lavy S, Culp CH. Identification of parameters for embodied energy measurement: A literature review. Energy Build 2010;42:1238-47. doi:10.1016/j.enbuild.2010.02.016.

[10] Dixit MK, Fernández-Solís JL, Lavy S, Culp CH. Need for an embodied energy measurement protocol for buildings: A review paper. Renew Sustain Energy Rev 2012;16:3730-43. doi:10.1016/j.rser.2012.03.021.

[11] Cabeza LF, Barreneche C, Miró L, Morera JM, Bartolí E, Fernández Al. Low carbon and low embodied energy materials in buildings: A review. Renew Sustain Energy Rev 2013;23:536-42. doi:10.1016/j.rser.2013.03.017.

[12] Moncaster a. M, Symons KE. A method and tool for "cradle to grave" embodied carbon and energy impacts of UK buildings in compliance with the new TC350 standards. Energy Build 2013;66:514-23. doi:10.1016/j.enbuild.2013.07.046.

[13] ISO/EN 14040. Environmental management - life cycle assessment - principles and framework (ISO 14040:2000). 2000.

[14] Zabalza Bribián I, Aranda Usón A, Scarpellini S. Life cycle assessment in buildings: State-of-the-art and simplified LCA methodology as a complement for building certification. Build Environ 2009;44:2510-20. doi:10.1016/j.buildenv.2009.05.001. 
[15] Monteiro H, Freire F. Life-cycle assessment of a house with alternative exterior walls: Comparison of three impact assessment methods. Energy Build 2012;47:572-83. doi:10.1016/j.enbuild.2011.12.032.

[16] Islam H, Jollands M, Setunge S, Ahmed I, Haque N. Life cycle assessment and life cycle cost implications of wall assemblages designs. Energy Build 2014;84:33-45. doi:10.1016/j.enbuild.2014.07.041.

[17] González-García S, Lozano RG, Estévez JC, Pascual RC, Moreira MT, Gabarrell X, et al. Environmental assessment and improvement alternatives of a ventilated wooden wall from LCA and DfE perspective. Int J Life Cycle Assess 2012;17:432-43. doi:10.1007/s11367-012-0384-0.

[18] Xing S, Xu Z, Jun G. Inventory analysis of LCA on steel- and concreteconstruction office buildings. Energy Build 2008;40:1188-93. doi:10.1016/j.enbuild.2007.10.016.

[19] Pérez G, Vila A, Rincón L, Solé C, Cabeza LF. Use of rubber crumbs as drainage layer in green roofs as potential energy improvement material. Appl Energy 2012;97:347-54. doi:10.1016/j.apenergy.2011.11.051.

[20] Cerón-Palma I, Sanyé-Mengual E, Oliver-Solà J, Montero JI, Ponce-Caballero $\mathrm{C}$, Rieradevall J. Towards a green sustainable strategy for social neighbourhoods in Latin America: Case from social housing in Merida, Yucatan, Mexico. Habitat Int 2013;38:47-56. doi:10.1016/j.habitatint.2012.09.008.

[21] Dean S, Marceau M, VanGeem M. Comparison of the Life Cycle Assessments of an Insulating Concrete Form House and a Wood Frame House. J ASTM Int 2006;3:13637. doi:10.1520/JAI13637.

[22] Richman R, Pasqualini P, Kirsh A. Life-Cycle Analysis of Roofing Insulation Levels for Cold Storage Buildings. J Archit Eng 2009;15:55-61. doi:10.1061/(ASCE)1076-0431(2009)15:2(55).

[23] Ramesh T, Prakash R, Shukla KK. Life cycle energy analysis of a residential building with different envelopes and climates in Indian context. Appl Energy 2012;89:193-202. doi:10.1016/j.apenergy.2011.05.054.

[24] Zabalza Bribián I, Valero Capilla A, Aranda Usón A. Life cycle assessment of building materials: Comparative analysis of energy and environmental impacts and evaluation of the eco-efficiency improvement potential. Build Environ 2011;46:1133-40. doi:10.1016/j.buildenv.2010.12.002.

[25] Papadopoulos AM. State of the art in thermal insulation materials and aims for future developments. Energy Build 2005;37:77-86. doi:10.1016/j.enbuild.2004.05.006.

[26] Anastaselos D, Giama E, Papadopoulos AM. An assessment tool for the energy, economic and environmental evaluation of thermal insulation solutions. Energy Build 2009;41:1165-71. doi:10.1016/j.enbuild.2009.06.003.

[27] Jelle BP. Traditional, state-of-the-art and future thermal building insulation materials and solutions - Properties, requirements and possibilities. Energy Build 2011;43:2549-63. doi:10.1016/j.enbuild.2011.05.015. 
[28] Pargana N, Pinheiro MD, Silvestre JD, de Brito J. Comparative environmental life cycle assessment of thermal insulation materials of buildings. Energy Build 2014;82:466-81. doi:10.1016/j.enbuild.2014.05.057.

[29] Schmidt AC, Jensen AA, Clausen AU, Kamstrup O, Postlethwaite D. LCA Case Studies A Comparative Life Cycle Assessment of Building Insulation Products made of Stone Wool , Paper Wool and Flax. Part 2. Int J Life Cycle Assess 2004;9:53-66. doi:10.1065/lca2003.12.144.1.

[30] Ardente F, Beccali M, Cellura M, Mistretta M. Building energy performance: A LCA case study of kenaf-fibres insulation board. Energy Build 2008;40:1-10. doi:10.1016/j.enbuild.2006.12.009.

[31] Kymäläinen H-R, Sjöberg A-M. Flax and hemp fibres as raw materials for thermal insulations. Build Environ 2008;43:1261-9. doi:10.1016/j.buildenv.2007.03.006.

[32] Zabalza Bribián I, Valero Capilla A, Aranda Usón A. Life cycle assessment of building materials: Comparative analysis of energy and environmental impacts and evaluation of the eco-efficiency improvement potential. Build Environ 2011;46:1133-40. doi:10.1016/j.buildenv.2010.12.002.

[33] Batouli SM, Zhu Y, Nar M, D'Souza NA. Environmental performance of kenaffiber reinforced polyurethane: a life cycle assessment approach. J Clean Prod 2014;66:164-73. doi:10.1016/j.jclepro.2013.11.064.

[34] Tettey UYA, Dodoo A, Gustavsson L. Effects of different insulation materials on primary energy and $\mathrm{CO} 2$ emission of a multi-storey residential building. Energy Build 2014;82:369-77. doi:10.1016/j.enbuild.2014.07.009.

[35] Densley Tingley D, Hathway A, Davison B. An environmental impact comparison of external wall insulation types. Build Environ 2015;85:182-9. doi:10.1016/j.buildenv.2014.11.021.

[36] CSIC. Instituto Eduardo Torroja. Catálogo de elementos constructivos del CTE. vol. 0. 2008.

[37] Vivienda M de la. Documento Básico HE Ahorro Energía. Madrid: 2013.

[38] ISOVER. Saint Gobain. Aislamiento de Fachadas. 2013.

[39] Dias AC, Boschmonart-Rives J, González-García S, Demertzi M, Gabarrell X, Arroja L. Analysis of raw cork production in Portugal and Catalonia using life cycle assessment. Int J Life Cycle Assess 2014;19:1985-2000. doi:10.1007/s11367-014-0801-7.

[40] Rives J, Fernandez-Rodriguez I, Rieradevall J, Gabarrell X. Integrated environmental analysis of the main cork products in southern Europe (Catalonia - Spain). J Clean Prod 2013;51:289-98. doi:10.1016/j.jclepro.2013.01.015.

[41] Rives J, Fernandez-Rodriguez I, Gabarrell X, Rieradevall J. Environmental analysis of cork granulate production in Catalonia - Northern Spain. Resour Conserv Recycl 2012;58:132-42. doi:10.1016/j.resconrec.2011.11.007. 
[42] Rives J, Fernandez-Rodriguez I, Rieradevall J, Gabarrell X. Environmental analysis of raw cork extraction in cork oak forests in southern Europe (Catalonia-Spain). J Environ Manage 2012;110:236-45. doi:10.1016/j.jenvman.2012.06.024.

[43] Baetens R, Jelle BP, Gustavsen A. Aerogel insulation for building applications: A state-of-the-art review. Energy Build 2011;43:761-9. doi:10.1016/j.enbuild.2010.12.012.

[44] IDAE. Sistemas de Aislamiento Térmico Exterior (SATE) para la Rehabilitación de la envolvente Térmica de los Edificios. Madrid: 2012.

[45] European Committee for Standardization. EN 15804:2012+A1, 2013.

Sustainability of construction works - Environmental product declarations - Core rules for the product category of construction products. 2014.

[46] Papadopoulos AM, Giama E. Environmental performance evaluation of thermal insulation materials and its impact on the building. Build Environ 2007;42:217887. doi:10.1016/j.buildenv.2006.04.012.

[47] Ingrao C, Lo Giudice A, Tricase C, Rana R, Mbohwa C, Siracusa V. RecycledPET fibre based panels for building thermal insulation: environmental impact and improvement potential assessment for a greener production. Sci Total Environ 2014;493:914-29. doi:10.1016/j.scitotenv.2014.06.022.

[48] Pfundstein M, Gellert R, Spitzner MH, Rudolphi A. Insulating materials: principles, materials, applications. Detail. Munich: 2012.

[49] PRé Consultants. Simapro 7.3.0 2010.

[50] Guinée J., Gorrée M, Heijungs R, Huppes G, Kleijn R, Koning A de, et al. Handbook on life cycle assessment. Operational guide to the ISO standards. I: LCA in perspective. Ila: Guide. Ilb: Operational annex. III: Scientific background. Dordrecht: Kluwer Academic Publishers; 2002.

[51] Itec M. Online IteC Database: Prices, Technical Details, Companies, Certificates, Product Pictures and Environmental Data. 2010. http://www.itec.cat/metabase.

[52] ecoinvent database 3.1. ecoinvent database 3.1. Swiss Cent Life Cycle Invent 2009. http://www.ecoinvent.ch/.

[53] Oliver-Solà J, Josa A, Rieradevall J, Gabarrell X. Environmental optimization of concrete sidewalks in urban areas. Int J Life Cycle Assess 2009;14:302-12. doi:10.1007/s11367-009-0083-7.

[54] Sanjuan-Delmás D, Petit-Boix A, Gasol CM, Villalba G, Suárez-Ojeda ME, Gabarrell X, et al. Environmental assessment of different pipelines for drinking water transport and distribution network in small to medium cities: a case from Betanzos, Spain. J Clean Prod 2014;66:588-98. doi:10.1016/j.jclepro.2013.10.055. 